\title{
Organic Production of Industrial Crops in Serbia
}

\author{
Jelena Golijan* · Ljubiša Živanović · Ljubiša Kolarić \\ Faculty of Agriculture, University of Belgrade, Nemanjina 6, 11080 Belgrade - Zemun, Serbia
}

\begin{abstract}
Summary: Organic production is a form of sustainable agriculture which protects human health and agro-ecosystems, and provides a significant economic profit. Since the area under this type of agricultural production increases throughout the world, the production of organic industrial plants records a trend of permanent increase. The aim of this study was to show the production status and production areas in Serbia for the period of 2013-2015. During the analyzed period, the area under this type of production increased by $75 \%$. The highest organic production of industrial plants is concentrated in Vojvodina. The area increased twofold in 2014, while in 2015 a threefold increase of area was recorded (compared to 2013 data). Serbia has very favorable conditions for organic crop production, as well as an additional investment to support producers, facilitate greater dissemination of their products to foreign markets, which have unlimited demand.
\end{abstract}

Key words: areas, industrial crops, organic crop production, regions

\section{Introduction}

Organic production is created as a response to human environmental pollution, urbanization and the preservation of flora and fauna, where the use of pesticides in conventional agriculture not only prevents the loss of crop protection from pests and pathogens, but has many negative consequences on the environment, as well as on market, because it leads to increased cost of agricultural products (Golijan and Popović, 2016; Golijan, 2016). The main concept of organic production is to protect the environment, and existing natural resources (Veličković et al., 2016; Subić et al., 2010; Golijan and Veličković, 2015), so it is technically applicable, socially acceptable and economically sustainable (Ubavić, 2015), and represents the alternative to the conventional production (Popović et al., 2016; Carić and Babović, 2012).

In Serbia, the regions and macrorayons of agriculture are clearly defined, which is of the particular importance in regional development and economic policy of the whole agriculture, not just of the villages (Babović et al., 2005). Serbia has fertile soils and significant level of non-contaminated land for a diverse agricultural and organic production. Region deployment and results related to land, air and water quality show that it is possible to successfully develop organic agricultural production and processing. Using modern technologies and biotechnology in production and

Corresponding author:

helena.ilios@gmail.com processing, with adequate global and regional development strategy, can significantly increase the production of organic foods, increase exports, make profits and protect the environment. The structure of agricultural production is conditioned by economic and natural diversity and characteristics of agricultural areas in Serbia. In the lowland area, arable land is most frequent, of which $72 \%$ is under corn, $19 \%$ under industrial crops, vegetables below $5 \%$ and $4 \%$ under forage crops. In plain-hilly area arable land is occupied by $75-92 \%$, with production dominated by cereals and fruits. The hilly-mountain rayon has less arable land, only $35-55 \%$, and the most common are pastures and forests, while crop and vegetable production is present to a lesser extent. In the hilly area, the soil is of poor quality, there are small plots and land is not suitable for agricultural production (Babović, 2010; Tasić, 2015).

In 2013, organic production of industrial crops globally spread over an area of 23,964 ha, and in 2014 it recorded an increase of 4.8\% (25,123 ha). In European countries, total organic production was carried out on an area of 12,378 ha in 2013 to reach an increase of $8 \%$ (13,373 ha) in 2014 (Willer and Lernoud, 2016; Golijan and Popović, 2016; Popović et al., 2017). Leading industrial crops producing countries are the USA, India, Brazil, and China. However, the organic production of industrial crops is mostly carried out in China, Kazakhstan, the USA, Romania, Ukraine, and Canada (Willer and Lernoud, 2015). The highest organic shares are in Peru 21\% (soybeans and peanuts), El Salvador $15 \%$ (sesame), Austria 10.1\% (soya and sunflower seed), Israel 5.9\% and Kazakhstan 5.1\% (Willer and Lernoud, 2014; Willer and Lernoud, 2015). The largest share in 
general is occupied by the area under organic production of soybean - nearly $30 \%$, while $20 \%$ is under sunflower and peanut (www.organic-world.net).

The aim of this paper was to show the state of organic production of industrial crops in Serbia, according to regions and districts, for the period 2013-2015.

\section{Material and Method}

Organic production of industrial crops occupies a significant share on the global level, in comparison with the entire sector of organic production. Considering the area under organic crops in Serbia, it is evident that it takes an important place. The desk research method was applied. Using literature data covering topics of organic agricultural production, industrial crops, and data available from the Ministry of Agriculture and Environmental Protection and the Serbian Chamber of Commerce, the paper analyzed and graphically displayed (in Microsoft Excel 2007) the trend of land area under organic production of industrial crops on the entire territory of Serbia, as well as in individual regions and districts in the period 2013-2015.

\section{Results and Discussion}

Basic characteristics of industrial crops production in Serbia over the last few years have been as follows (www.seedev.org): 1) the participation of soybean crop in sowing structure is on extremely high level, not typical for European countries which stopped growing soybean long time ago and became dependent on imports of soybean and its meal from the United States,
Brazil, and Argentina (about 300,000 ha have been planted); consequently, more than $40 \%$ of soybean production in the EU is of Serbian origin, 2) reduced number of sugar beet producers, with a significant improvement in productivity and yield (which provides an opportunity for Serbia to produce sufficient quantities of sugar, both for the domestic market and for export), 3) despite the high price in 2014, sunflower production areas did not increase (although, according to the expectations, a significant decrease in production areas will happen with reduced price), and 4) large variability in the total production of industrial crops, especially soybean - great effect of favorable or unfavorable years for producing.

Organic production in Serbia recorded a rising trend (Veličković and Golijan, 2016). The total area under this type of agricultural production in 2015 spread out over an area of 15,298.02 ha (Ministry of Agriculture and Environmental Protection, 2016). In the range of organic production in Serbia tillage plant production takes $72 \%$. The part of the area under organic production in the total used agricultural land is $0.23 \%$ (Bošković, 2016). The highest export value in 2013 was achieved by the export to Germany, the Netherlands, the USA, Great Britain and Switzerland. In 2013, 7,100 tons of organic products were exported, which is 10.7 million euros worth (Center for Organic Production, 2016). Production of industrial crops in Serbia (tobacco, flax, poppy seeds, sorghum, soybean, sunflower, rapeseed), with an area of 2,674.38 ha in 2015 takes the third place, while the leading role is taken by cereal production (4,251.94 ha) (Golijan, 2016, Popović et al., 2017)(Fig. 1).

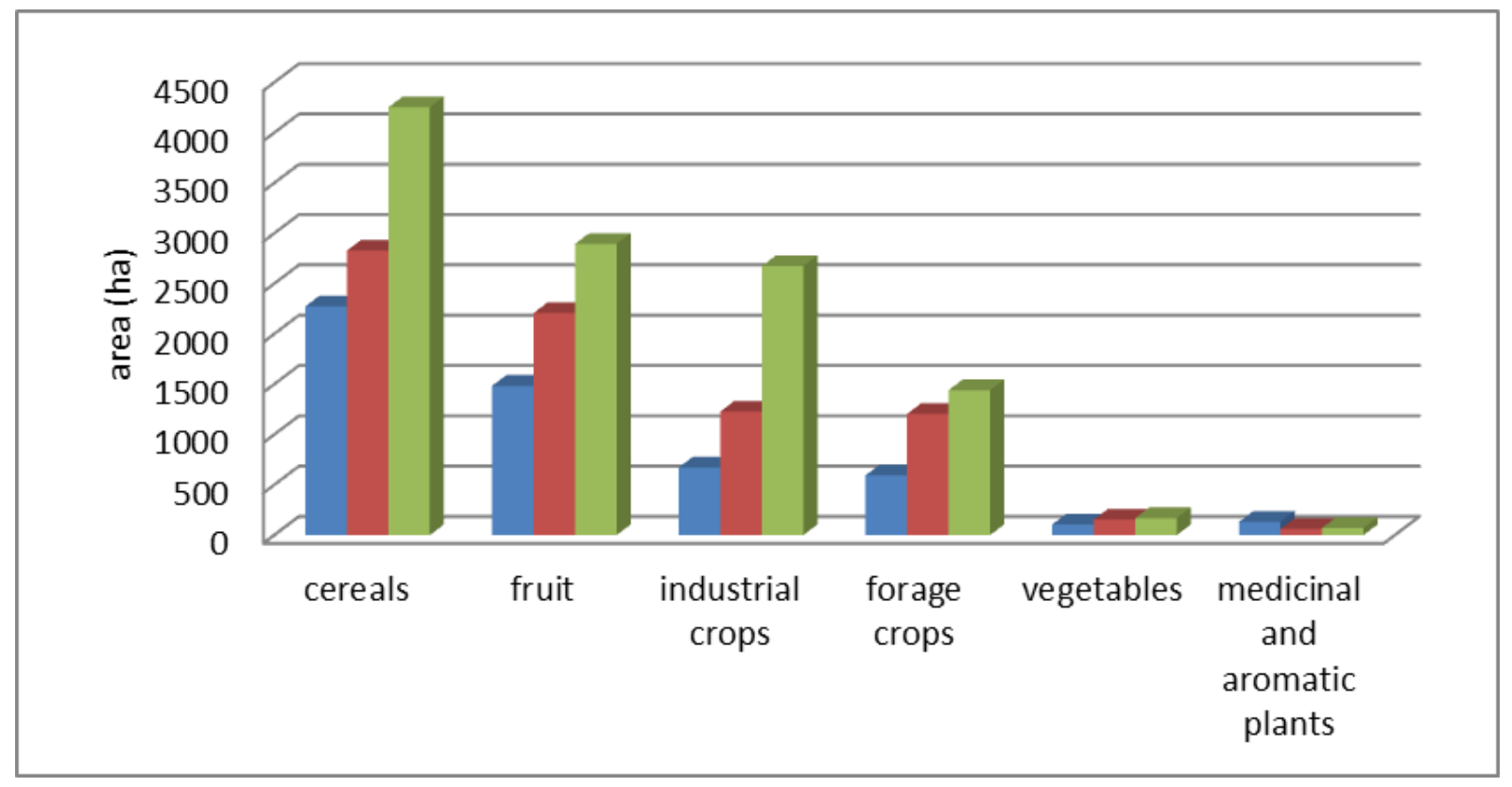

Figure 1. The structure of the organic crops production in Serbia (2013-2015) 


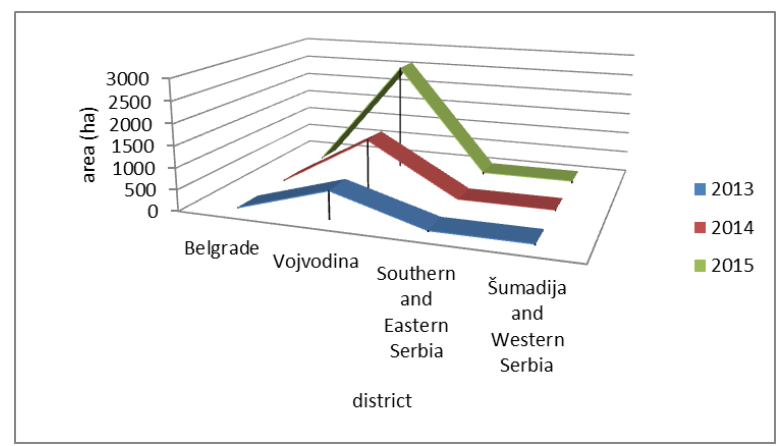

Figure 2. The distribution of area (ha) under organic production of industrial crops by regions in the period 2013-2015

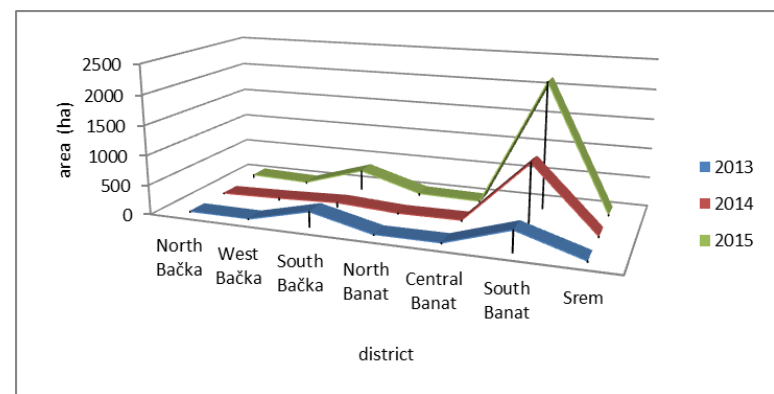

Figure 3. Area (ha) under organic production of industrial crops in the region of Vojvodina (districts) in the period 2013-2015

According to the report of the Serbian Chamber of Commerce on industrial crops in 2015, the highest production value was achieved by soybeans (50.8 million, or 129,585 t), and soybean oil (46.1 million, or 6,5217 t) (Serbian Chamber of Commerce, 2016). In the period from 2013 to 2015, the area under organic production of industrial crops increased by $75 \%$. The lowest areas under this type of production are in the region of the City of Belgrade (9.5 ha in 2015, 0.5 ha in 2014, and 0.97 ha in 2013) (Fig. 2).

During the period from 2013 to 2015, the largest area under organic production of industrial crops was in the region of Vojvodina. South Banat District is a district in which the highest organic production of these plants takes place during the three analyzed years. Compared to the year of 2013, the area increased threefoldin 2014, while in 2015 it increased twice (2,152.04 ha).

Also, in the region of Vojvodina, a very significant area under organic production of industrial crops is located in the South Bačka District, in the amount of 336.09 ha in 2015, which is an increase of 264.44 ha compared to 2014 (Fig.3). The lowest type of production in the region takes place in the Central Banat District (only 6.43 ha in 2015).

Organic production of industrial crops during 2015 in the region of Southern and Eastern Serbia took place on 33.47 ha, while in 2014 in either district, the area of this type of agricultural production was not registered (Ministry of Agriculture and Environmental Protection,
2016). In 2013, organic production took place on 14.89 ha. Podunavlje district was the only district with the registered areas under organic production of industrial crops in 2013 and 2015, while for the first time in 2015 the organic production of these crops took place in Pčinja district on the area of only 0.01 ha (Fig. 4).

In the region of Šmadija and Western Serbia, organic production of industrial crops took the second place after Vojvodina in 2013 on 13 ha, while in 2014 a decline in production by $85 \%$ was recorded. In 2015 , production reached an area of 37.85 ha (Ministry of Agriculture and Environmental Protection, 2016), which is an increase of $94.85 \%$ compared to 2014 (Fig. $5)$. The largest share of organic production of these types of plants in 2015 was in Mačva district and reached $97.81 \%$, while in 2013 this share was only $5.54 \%$. In addition to Mačva district, the only district of the region in which organic production of industrial crops took place was Pomoravlje district. In 2013, with area of 12.29 ha $(94.54 \%)$, it was the leading district in the region. However, after 2013, the area decreased in this district, which in 2014 occupied a share of only $6.67 \%$ and $2.22 \%$ in 2015 .

According to the altitude and the possibilities for development of agriculture and organic farming, Serbia is divided into four macrorayons: lowland, plain-hilly, hilly-mountain, and hill and mountain (Marković, 1995, Babović \& Veselinović, 2010; Tasić, 2015):

1) Lowland areas up to $200 \mathrm{~m}$ above sea level covers lowland macroreon including five microreons (cereal area; area of industrial crops, vegetables, fruits and grapes, and livestock reon). In this area, under current research of the natural resources, there are very good conditions for diverse organic agricultural production;

2) The plain-hilly reon of $200-500 \mathrm{~m}$ above sea level covers several parts of central Serbia (cereal and industrial crops, fruits and grapes, vegetables and livestock reon), in which natural resources are favorable for a diverse organic production;

3) The hilly-mountain reon of $500-1000 \mathrm{~m}$ above sea level includes two parts of central Serbia (croplivestock-fruit-wine region). This sector, from the point of agro-ecological and environmental conditions, is very favorable for the development of organic agriculture;

4) The hilly and mountainous areas over $1000 \mathrm{~m}$ above sea level, comprises two parts of central Serbia and Kosovo and Metohija, which have all the conditions for the development of traditional and organic production.

Organic farming is one of the fastest growing sectors. This is supported by the fact that in the last five years, the area under this type of agricultural production increased by almost 300\% (Golijan et al., 2017; Kolašinac et al., 2017). In 2015, the percentage of area under organic production in the total agricultural land reached $0.44 \%$. In comparison, the 
average in the EU, according to data from 2013 was close to 5.4\% (Center for Organic Production, 2016). In order to expand organic grain production, industrial and herbs, the Ministry of Education and Science of the Republic of Serbia, funded by the project of integrated and interdisciplinary research "Sustainable agriculture and rural development in achieving the strategic goals of the Republic of Serbia the Danube region" no. 46006 III) in the period from 2011-2014, in which the stated task was: organic production of cereals, industrial and herbs in order to create brands through a vertical model of association (Berenji et al., 2013). The analyses of the project show (according to the available data) that few examinations have been taking place on the certified organic farms; farmers and their cooperatives and private sector on the whole have not taken part enough in fulfilling the goals of the project. The aims of the project were not achieved enough and it is usually concluded that they are necessary to be continued. In general, the application of the results in the organic production sector is insufficient.

The main characteristic of organic production in Serbia is that there are two basic groups of organic producers: individuals (they directly made agreements with some of the controlling organizations) and the so called cooperators (Oljača, 2015). Their production is the subject of group certification allowed by the current law of the Republic of Serbia. The cooperators have contracts with companies that purchase their whole production intended for the export markets. At the same time, they support them with inputs and education, and also cover the certification costs, whereby the holder of the certificate is the company and not the producers themselves (Kalentić et al., 2014).

The characteristic of organic farms in the region of Vojvodina is their specialization for the production of a lesser number of plant species, such as cereals, industrial crops and vegetables, while the average farm size is larger than 10 ha. In contrast, farms in central Serbia are mainly cooperatively related to private processing facilities. Their necessary inputs are provided by buyers and their production is set up on small areas. With a production area of more than 500 ha, large private companies represent the third group of Serbian farms. Their characteristic is the deficiency of infrastructure-specialized equipment and personnel and they are under considerably large investments for the supply of equipment and machinery (Berenji et al., 2013). In comparison with other segments of the agribusiness sector, organic production can provide a very significant income, even with a small investment, and this fact makes it one of the biggest advantages of investing in this type of environmentally friendly and healthy agricultural production.

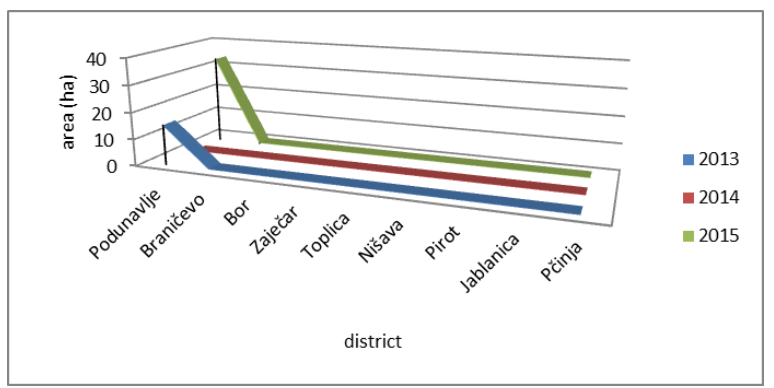

Figure 4. Area (ha) under organic production of industrial crops in the region of Southern and Eastern Serbia (districts) in the period from 2013-2015

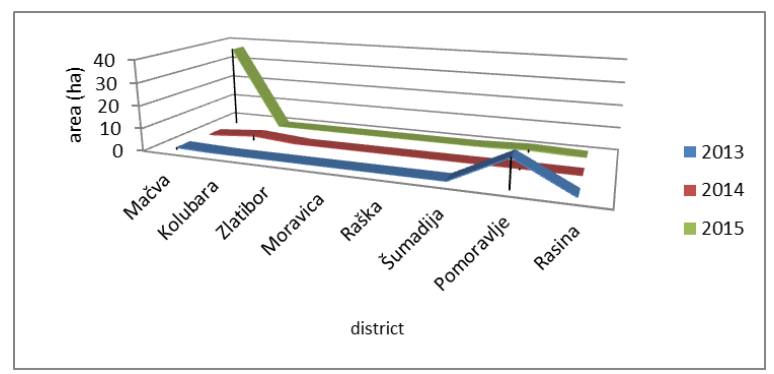

Figure 5. Area (ha) under organic production of industrial crops in the region of Šumadija and Western Serbia (districts) in the period 2013-2015

\section{Conclusions}

Vojvodina is the leading region for the largest organic production of industrial crop, where the largest share concentrated in the South Banat District, followed by South Bačka with 336.09 ha. After Vojvodina, in the region of Šmadija and Western Serbia, the largest manufacture of industrial plants is carried out according to organic principles, which in comparison to the year 2013 had a decline in production by $85 \%$, after which in 2015 it was followed by an increase of $94.85 \%$ compared with 2014.

Mačva district had the largest share of production in the region, followed by Pomoravlje district. In the region of Southern and Eastern Serbia, organic industrial crop production takes place in an area of 33.47 ha, which is the only Podunavlje district county with registered production in 2013 and 2015, while in 2015, and in Pčinja district, for the first time production took place on the area of only 0.01 ha.

The City of Belgrade had the lowest production of organic industrial plants in 2013 and 2015 (0.97 and 9.51 ha, respectively). With regard to organic production of industrial crops in Serbia is in third position, behind cereals and fruits, in addition to favorable natural conditions, especially in the Vojvodina region, it is necessary to associate their producers, as well as the support of the state in the form of grants and projects in order to improve production and better marketing of their products in foreign markets. 


\section{References}

Babović, J., Lazić, B., Malešević, M., \& Gajić, Ž. (2005). Agrobiznis u ekološkoj proizuodnji hrane. Novi Sad: Naučni institut za ratarstvo i povrtarstvo.

Babović, J. (2010). Reonizacija - uslov agrarnog razvoja $i$ organske poljoprivrede Srbije. Međunarodni simpozijum, Centar za strateška istraživanja nacionalne bezbednosti Beograd, Sijarinska banja.

Babović, J. \& Veselinović, B. (2010). Agrama politika EU i reonizacija agrarne proizvodnje Srbije. Zbornik radova. Novi Sad: Fimek.

Berenji, J., Milenković, S., Kalentić, M., \& Stefanović, E. (2013). Nacionalna istraživačka agenda za sektor organske proizuodnje. ACCESS-Program for development of private sector in Serbia, Belgrade: GIZ.

Bošković, D. (2016). Control and certification of organic agricultural production. Ekonomija: teorija i praksa, 9(2), 87-111.

Centar za organsku proizvodnju (2016). Osnovne informacije o organskoj proizvodnji u Srbiji. Beograd: Privredna komora Srbije. Retrieved from http://www.pks.rs/SADRZAJ/Files/OPC\% 20Brosura.pdf. Accessed on 24 March 2017.

Carić, M. \& Babović, J. (ed.) (2012). Organska prerada. Novi Sad: Fimek.

Golijan, J. \& Veličković, M. (2015). Nutritivni sastav organski i konvencionalno proizvedenih namirnica. Hrana $i$ ishrana, 56(2), 43-46.

Golijan, J. (2016). Motivi koji utiču na kupovinu organskih prehrambenih proizvoda. Agroekonomika, 45(72), 73-80.

Golijan, J. (2016). Organska proizvodnja lekovitog i aromatičnog bilja u Republici Srbiji. Lekovite sirovine, 36(36), 75-83.

Golijan, J. \& Popović, A. (2016). Basic characteristics of the organic agriculture market. Fifth International Conference Competitiveness of Agro-Food And Environmental Economy, 10-11 November 2016, Bucharest.

Golijan, J., Živanović, Lj. \& Popović., A. (2017). Status and areas under organic production of vegetables in the Republic of Serbia.6 $6^{\text {th }}$ International Symposium on Agricultural Sciences (AgroRes 2017), February 27-March 2, 2017 Banja Luka, Republic of Srpska, Bosnia and Herzegovina, pp. 133.

Kalentić, M., Stefanović, E., Simić, I., \& Maerz, U. (2014). Organska poljoprivreda u Srbiji 2014. Beograd: Nacionalno udruženje za razvoj organske proizvodnje Serbia organica.

Kolašinac, S., Golijan, J., Lekić, S., Moravčević, Đ., \& Popović, A. (2017). Challenges and possibilities of organic seed production with the emphasis on control of pathogens. $6^{\text {th }}$ International
Symposium on Agricultural Sciences (AgroRes 2017), February 27March 2, 2017 Banja Luka, Republic of Srpska, Bosnia and Herzegovina, pp. 143.

Marković, P. J. (1995). Poljoprivredni atlas Srbije. Beograd: Ministarstvo poljoprivrede, šumarstva i vodoprivrede.

Ministry of Agriculture and Environmental Protection (2016). Database on agricultural production in Serbia. Retrieved from http://www.mpzzs.gov.rs/ Accessed on 20 December 2016.

Oljača, S. (2015). Kontrola i sertifikacija u organskoj proizvodnji u Srbiji (projekat Unapredenje organske poljoprivredne proizvodnje u zapadnoj Srbiji putem edukacije poljoprivrednih proizvođača). Beograd: Ministarstvo poljoprivrede, šumarstva i vodoprivrede. Retrieved from http://arhiva.nara.ac.rs/ handle/123456789/1562 Accessed on 24 March 2017.

Popović, A., Golijan, J., Babić, V., Kravić, N., Sečanski, M. \& Delić, N. (2016). Organic farming as a factor for biodiversity conservation. International scientific conference on Ecological crisis: Technogenesis and climate change. Belgrade, 21-23 April 2016.

Popović, A., Golijan, J., Sečanski M., \& Čamdžija, Z. (2017). Current status and prospects of organic production of cereals in the world. 6th International Symposium on Agricultural Sciences (AgroRes 2017), February 27-March 2, 2017 Banja Luka, Republic of Srpska, Bosnia and Herzegovina, pp. 102.

Serbian Chamber of Commerce (2016). Database. Retrieved from http://www.pks.rs/ Accessed on 1 January 2016.

Subić, J., Bekić, B., \& Jeločnik, M. (2010). Značaj organske poljoprivrede u zaštiti životne sredine i savremenoj proizvodnji hrane. $\check{S}$ kola biznisa 3, 50-56.

Tasić, S. (2015). Implementacija agroekonomske politike EU na poljoprivredni $i$ ruralni razvoj Srbije. Doctoral dissertation, Univesity of Privredna akademija in Novi Sad.

Ubavić, P. (2015). Uloga organske proizvodnje u razvoju ruralnog turizma u Srbiji. Agroekonomika, 44(66), 69-81.

Veličković, M., \& Golijan, J. (2016). Organic Fruit Production in Serbia. Agro-knowledge Journal, 17(3), 289-297.

Veličković, M., Golijan, J., \& Popović, A. (2016). Biodiversity and organic agriculture. Acta Agriculturae Serbica, 21(42), 123-134.

Willer, H. \& Lernoud, J. (Eds) (2015). The World of Organic Agriculture. Statistics and Emerging Trends 2015. FiBLIFOAM Report. Research Institute of Organic Agriculture (FiBL), Frick, and IFOAM Organic International, Bonn.

Willer, H. \& Lernoud, J. (Eds) (2016). The World of Organic Agriculture. Statistics and Emerging Trends 2015. FiBLIFOAM Report. Research Institute of Organic Agriculture (FiBL), Frick, and IFOAM Oragnic International, Bonn.

\section{Organska proizvodnja industrijskog bilja u Srbiji}

\section{Jelena Golijan · Ljubiša Živanović · Ljubiša Kolarić}

Sažetak: Organska poljoprivredna proizvodnja predstavlja vid održive poljoprivredne proizvodnje, štiteći zdravlje ljudi, agro- i ekosistem, a pri tome osigurava značajan ekonomski profit. Kako se površine pod ovim vidom poljoprivredne proizvodnje uvećavaju širom sveta, tako i proizvodnja organskog industrijskog bilja beleži trend permanentnog rasta. U tom cilju, želeli smo da prikažemo stanje proizvodnih površina u Srbiji za period od 2013 2015. godine. U analiziranom periodu od 2013. do 2015. godine površine pod ovim vidom proizvodnje uvećane su za 75\%. Najveća organska proizvodnja industrijskog bilja skoncentrisana je u Vojvodini. U odnosu na 2013. godinu, u 2014. godini površine su dvostruko uvećane, dok je u 2015. godini zabeleženo trostruko uvećanje površina (u poređenju sa podacima iz 2013. godine). Srbija poseduje izuzetno povoljne uslove za organsku proizvodnju industrijskog bilja, te bi uz dodatnu investicionu podršku proizvođačima omogućila veće širenje njihovih proizvoda na inostrana tržišta, koja imaju neograničenu potražnju.

Ključne reči: industrijsko bilje, organska proizvodnja, površine, regioni 